\title{
Muslim Education and Interfaith Understanding: The Case of the Muslim College in the United Kingdom
}

\author{
Suwito $^{\text {a }}$, Yusuf Rahman ${ }^{\mathrm{a}}$, Izza Rohman ${ }^{\mathrm{b}}$ \\ ${ }^{a}$ Syarif Hidayatullah State Islamic University Jakarta, J1. Ir. H. Djuanda 95, Ciputat, Indonesia \\ bUniversitas Muhammadiyah Prof. Dr. Hamka, Jl. Limau 2, Kebayoran Baru, Jakarta Selatan, Indonesia \\ Corresponding e-mail: swt@uinjkt.ac.id
}

\begin{abstract}
In a multicultural society, Islamic education that is conscious of the need for creating social harmony across faiths and denominations has more to offer than confessional education in Islamic seminaries and secular universities' critically approached by Islamic studies. Muslim higher educations in the United Kingdom have clearly reflected their awareness of the importance of interfaith and intrafaith understanding in many aspects, and thereby increase their capability to enhance the career prospects of their students while giving them a sense of piety and criticality at the same time. This research challenges some assumptions that Muslim education in a secular country is more driven by Muslims' responses to the secular, modern world; and that Muslim education in a non-Muslim majority country is shaped more by majority-minority dynamics; and that Muslim education in the West is oriented more toward missionary objectives. On the other hand, this research strengthens the notion that Muslim education in the modern world is guided more by the need to establish relevance in education. This study, which combines both library and field research methods, finds that higher education institutions run by Muslims in the United Kingdom have consciously offered their students with curriculum, resources, and educational environment that are friendly to diversity of faiths and diversity within Islam in an attempt to make their skills and knowledge relevant to multicultural British society.
\end{abstract}

Keywords: Interfaith relations, higher education, British Muslims, Islamic Studies, Islamic seminaries.

\section{INTRODUCTION}

The discussion on Islam in the West is often centered on some issues such as integration, inclusion, radicalization, tolerance and pluralism. In terms of its influence on the issues of religious freedom and pluralism, the existence of Islam in the West has been seen differently in previous studies. Some assumes that Islam, usually perceived as a monolithic block, provides a greater challenge for religious freedom and pluralism that have already settled. Islam is seen as a threat to the culture of respect for religion characterizing the modern, secularized West. They emphasize the incompatibility of Islam with Western values. Others tend to see that Islam can play a positive role in sustaining and advancing Western cultural values regarding religious pluralism.
Within Islam itself, religious pluralism - an ambiguous and complex idea - has triggered a serious debate among scholars. It has been unavoidable due to various reasons, such as plurality of religious pluralisms (alethic, soteriological and normative) (Abdullah, 2014, p. 23), a plurality of understanding of Islamic texts, such as around ethical foundations in the Qur'an on which arguments in favor of religious pluralism can be built, and a plurality of attitudes shaped by historical circumstance concerning interfaith relations.

Partly to shed light on how Islam/Muslims in the West deal with the question of religious pluralism, this study highlights the relationship between Islam in the United Kingdom and interfaith understanding. There are at least three reasons why the relationship is worthy of a closer look. First of all, Britain has been renowned for its multiculturalism and moderate secularism. Twenty-first century 
Britain is noticeably characterized by striking diversity: different races, religions and cultures. British society is even rapidly changing and more diverse. While British society is described as "threedimensional" since it considers Christianity, secularity and religious plurality to be equally important,(Scott-Baumann \& CheruvallilContractor, 2015, p. 7) over the last decade, Britain has been seen as becoming less Christians, more nonreligious and more religiously plural (Scott-Baumann \& Cheruvallil-Contractor, 2015, p. 75; Modood, 2015, p. 8) Even within Christianity in the country, the community is increasingly plural because there has been a decline of the Anglicans in number, and there has been an increase of the Evangelists or other new churches and other denominations (Kessler, 2016) and also an increase of the number of Christians who abandoned their family faith to have "no religion" ("People of No Religion Outnumber Christians in England and Wales-Study,": $\{$ "for

Religious plurality in Britain is recognizably marked by freedom to practice one's own religion, intercultural dialogue and community cohesion (Scott-Baumann \& Cheruvallil-Contractor, 2015, p. 75). This is particularly due to its multiculturalism and moderate secularism. It is in the midst of its moderate secularism that the growth of Islam in Britain can not only change the character of religion in the country, but also serve as the lightning rod for the debate on the public role of religion (Gilliat-Ray, 2010, p. 262; Birt, Hussain, \& Siddiqui, 2011, p. v). It is argued that Islam and the rise of multi-faith Britain has had a major impact on the discussions on the relationship between religion and the state in the country (Birt et al., 2011, p. xx).

Moderate secularism defines secularism neither as absolute separation of religion and the state, nor as the state's control of religions, but as mutual autonomy and mutual support between religion and the state. Even though it may take different forms and be institutionalized in different ways, Britain is very much a part of this Western European mainstream culture (Modood, 2015, p. 4)

Secondly, in its religiously diverse society, there have been a lot of interfaith initiatives in the United Kingdom, on the one hand, and a sense of fear and suspicion among different religious communities, most notably fear of Islam/Muslims (as is the case with other Western countries), on the other hand. Interfaith dialogue and cooperation are taking place quite frequently in the country. In Britain, interfaith dialogue has sometimes be regarded as "a powerful industry". It is reported that between 1987 and 2015, the number of interfaith organizations increased from 30 to over 230 (Commission on Religion and Belief in British Public Life, 2015, p. 51). There has also been an increase in the growth of interfaith organizations with a special focus like the Christian-Muslim Forum, the Hindu-Christian Forum, the Joseph Interfaith Foundation (working on Jewish-Muslim dialogue), in addition to the UK branches of international interfaith organizations like Religions for Peace (Commission on Religion and Belief in British Public Life, 2015, p. 51). Many of those working on interfaith issues have been linked through The Inter Faith Network (IFN) for the UK, which consists of bodies within four categories of membership: Educational and Academic Bodies; Local Inter Faith Member Bodies; National and Regional Inter Faith Member Bodies; and National Faith Community Representative Bodies. Founded in 1987, the IFN seeks to promote understanding and respect between different faith groups.

On the other hand, Islam phobia, irrational hostility towards Islam and fear of Muslims (that often lead to hate crimes against Muslims), is still an issue (Awan \& Zempi, 2015) Islam phobia is even an issue in schools and universities, where there is a concern over knowledge of Islam among nonMuslims that is supposed to help break down prejudice and counter Islam phobia. The existence of interfaith initiatives going on and fear of Islam that continues to be an issue, help us see the case of Islam in Britain as an interesting, important one.

Thirdly, Islam in Britain is not only the country's second largest religion today, but also theologically and sociologically diverse. It is growing, but also changing fast. While selfidentifying Muslims constituted 2.7 percent of the total UK population according to data from the 2001 census (3.0 percent for England and Wales), the percentage has increased significantly to 4.4 percent in the results of the 2011 census (4.8 percent for England and Wales) (Scott-Baumann \& CheruvallilContractor, 2015, pp. 157e6". The Muslim population in England and Wales has increased from 1.55 million in 2001 to 2.71 million in 2011. There are 77,000 Muslims in Scotland and 3,800 in Northern Ireland. Overall, based on 2001 and 2011 censuses, England and Wales witness an increase in the population reporting no religion, a drop in the population reporting to be Christian, and an increase in all other main religions, with the increase of the number of Muslims being the most.

As Tim Winter (aka Abdal Hakim Murad, ac cited in Scott-Baumann \& Cheruvallil-Contractor, 2015, p. ix; Gilliat-Ray, 2010, p. 118) mentions, Islam is today the most seriously followed of British religions particularly in some urban contexts. British Muslims cannot be seen as a single discrete category. They include different ethnicities, races, classes, nationalities, and identities. A study in 2005 claimed that Muslims in the UK have 56 nationalities, speak 70 languages and pray in more than 1,200 mosques 
(Dike, 2009, p. 7). More than half (53\%) of the Muslim population are not UK-born (The Muslim Council of Britain, 2015). Moreover, they are also so diverse in terms of theological background. It is illustrated that in Britain, "Pakistani Barelwi must coexist with the Turkish Sufi, the Iranian Shia and the Saudi Arabian Wahabi" (Scott-Baumann \& Cheruvallil-Contractor, 2015, p. 161).

\section{METHODS}

In examining the role of Muslim higher education in the United Kingdom in promoting interfaith and interfaith understanding, this study defines Muslim higher education as faith-based higher educational institutions run by Muslims, i.e. colleges and academic institutions offering undergraduate and postgraduate programs with a predominantly Islamic character. Elements of higher education examined include mainly the content (curriculum), the actor (academics), the institution's mission and activities, and the management (mainly partnership).

This study focuses on what roles played by Muslim higher education in promoting interfaith and interfaith understanding. Identifying the roles, we focus on highlighting some important questions as follows: 1) What are the stated vision, mission, aims and objectives of the Muslim higher educations that reflect their awareness of the importance of peaceful interfaith and/or interfaith relations?; 2) To what extent do the academics of Muslim higher education get involved in interfaith initiatives?; 3) What are offered by the Muslim higher educations through their curriculum to help promote interfaith and interfaith understanding to their students?; 4) What are the partnership across faiths/denominations the Muslim higher educations have that help promote interfaith and interfaith understanding?

The list of the recognized colleges includes The Muslim College in London, Institute of Ismaili Studies in London, The Islamic College in London, the Markfield Institute of Higher Education in Leicester, al-Maktoum College of Higher Education in Dundee, Scotland, Cambridge Muslim College in Cambridge, Cambridge Islamic College in Cambridge, Ebrahim College in London, and alMahdi Institute in Birmingham. This paper just would like to discuss The Muslim College.

\section{RESULT: INTRA-AND- INTERFAITH UNDERSTANDING IN THE MUSLIM COLLEGE}

The Muslim College in London basically has a Sunni root and an Azhari link, but it claims to not favour or subscribe to any particular denomination of Islam. This means that it opens the door for those coming from different denominations: Sunni, Shi'a and others. In addition, The Muslim College even seeks to encourage mutual respect and understanding between various Muslim communities.

While most of the students and staffs have Sunni origin, this openness is in line with the Azharian position with regard to difference in Islam, and most importantly with the thought of The Muslim College's founder and first principal, Mohammed Zaki Badawi we would discuss later on. Zaki Badawi is even renowned for his great interest in interfaith dialogue and mutual understanding. It is then understandable that The Muslim College states that it seeks to inform Muslims about other faiths in the hope that understanding will lead to respect and harmony.

The Muslim College employs both Western and traditional scholarship. This means that it acknowledges the value of both modern-Western and classical-Islamic scholarship and has a commitment to link the two civilizations sometimes believed to be incompatible. The College also allows for equality of the sexes, where men and women are taught together and are encouraged to fully participate in classes. This emphasis means that it avoids to situate its learning in a segregation and heavily monologue setting. Part of its commitment to cross-cultural understanding, The Muslim College even allows people of all (or no) faiths to come and study. While naturally the students come from Muslim background, this commitment to diversity reflects the College's openness toward interfaith dialogue and multicultural education, as well as its dedication to serve wider society (not only Muslims).

The Muslim College has three stated objectives: 1) to provide a comprehensive Islamic education to all who wish to learn about Islam without prejudice; 2) to provide platforms for other faith communities, NGOs, charities, organizations so as to convey the spirit of multiculturalism and interfaith dialogue that is befitting to Islamic belief; and 3) to ease tensions within communities by offering advice, services and pastoral care, and providing opportunities and spaces to examine and explore faiths in the West. Reflected in these three objectives is a spirit to provide Islamic Studies that can help create harmony in a multi-faith society. 
Students at The Muslim College are expected to "develop a critical approach to traditional and contemporary issues of religion, and to combine theoretical, vocational and practical experiences in their evaluation of a religiously plural society." In addition to this expectation, students there are "encouraged to develop an appreciation of the challenges that modern life poses to religion in general and Islam in particular, and to study in depth the impact that the interaction between Islam and modernity leaves on the pattern of culture, belief and social behavior" (http://muslimcollege.ac.uk; and Drammeh, 2016).

The Muslim College is regarded as one of formal educational institutions that serve as a response to the phenomenon of British-born children from Muslim family being educated by those rooted in the traditions of Muslims outside (Pakistan, Saudi Arabia etc.). The same phenomen is the one also responded by the emergence of some other Muslim educational institutions like the Hijaz Institute in Coventry.

In The Muslim College, its founder and former principal, Sheikh Mohamed Aboulkhair Zaki Badawi (1922-2006) was an internationally known Islamic scholar and promoter of interfaith dialogue. He was one of the three founders of Three Faiths Forum (3FF), a well-known interfaith organization that "works to build good relations between people of different faiths, beliefs and cultures" and a member of the Inter Faith Network IFN). 3FF seeks to run education, engagement and action programmes that bring diverse communities together in the United Kingdom and beyond (particularly in the European Union, United States of America and Middle East).

Zaki Badawi was a Vice Chairman of the World Congress of Faiths, the Director and Chief Imam at London Central Mosque and Islamic Cultural Centre as well as the Chairman of the Imams and Mosques Council of the UK. The latter body was aimed at facilitating communication between mosques, solve internal disputes, and encourage cooperation and tolerance between mosques of various factions.

In 2004, Badawi was made an honorary Knight Commander of the Order of the British Empire (KBE). In recognition of his interfaith work, he was also appointed as Knight Grand Cross of the Royal Order of Francis I (GCFO) by The Duke of Castro. Zaki Badawi was born in Egypt, trained at al-Azhar University in Cairo, gaining an undergraduate degree in Theology and subsequently a master's degree in Arabic Language and Literature. He moved to the United Kingdom in 1951 and studied Psychology at the University College London, obtaining his BSc degree and then a PhD degree in Modern Muslim
Thought from the University of London (http://muslimcollege.ac.uk; Gilliat-Ray, 2010).

Badawi was once credited with having "revolutionised the training of Islamic thinkers in Britain, challenging the traditional, inward-looking, rule-based education of most British imams with a broad, multi-faith training grounded in western philosophical study."(ODDIN ZOTERO_ITEM He was regarded as the one who had done most to establish Islamic institutions in Britain.

In addition to Badawi's legacy in religious pluralism, The Muslim College now has some lecturers very much interested in religious pluralism or interfaith issues, such as Dr Ahmad Achtar, who is currently programme convenor of the BA Study of Religions and MA in Abrahamic Religions at Heythrop College of London University. Achtar is also involved in scriptural reasoning practice and is a member of Scriptural Reasoning University Group, Cambridge.

Dr Sejad Mekic is another lecturer having much interest in Islam and religious pluralism, interfaith dialogue, and scriptural reasoning - among others. Professor Shaikh Abdul Mabud is also a lecturer of The Muslim College, who has been actively involved in exploring common educational grounds with people of different faiths. Dr Alhagi Manta Drammeh is another lecturer in the college, who has a similar interest. Drammeh, who works at the Islamic Cultural Centre London as editor and reviewer of the Islamic Quarterly, published a book on The Fallacy of the Inevitability of Clash of Civilisations: A Common Ground for Mutual Understanding and Co-Existence (Kuala Lumpur: IIUM Press, 2009).

At The Muslim College, the curriculum also includes the study of both Islam and Western society, and emphasizes interfaith dialogue. In its MA in Islamic Studies, the sense of intrafaith understanding has been introduced in various courses, such as Qur'an and Hadith Studies, Islamic Law and Jurisprudence, Islamic Theology and Philosophy, and Islamic History and Civilisation (Drammeh, 2016). Its revised curriculum includes an optional module on Muslims in Britain.

The Muslim College's BA in Islamic Studies also offers compulsory modules like Islamic Law: Comparative 'Ibadat Law, Qur'anic Interpretation: Approaches and Commentaries, Minorities Fiqh: Issues and Challenges, and World Religion, and optional modules like Western Philosophy, Muslims in Britain, Islam and Inter-faith Relations, and World Religions. These MA and BA modules give the students an opportunity to have meaningful interfaith and interfaith understanding.

The Muslim College also has Community Leadership and Imam Ship Program whose courses help participants to know the Islamic concept of 
pluralism and universality, and their contemporary exemplification, critically look into the role of Imams Today in Britain, understand the challenges of multiculturalism and Muslim responses, and examine Islam, media and Islam phobia. The program offers 10 week lectures, with Islam and Pluralism being the subject of the second and third weeks. In addition, the College has often invited rabbis and clergy to talk to the students about non-Islamic faiths (particularly Judaism and Christianity). Some non-Muslim scholars can also work at the College to teach subjects like philosophy and world religions (Drammeh, 2016).

The Muslim College in Ealing, West London, which has a Sunni (Azhari) background but claims to be non-denominational, for years offered a Certificate and Diploma in Islamic Studies in collaboration with the Faculty of Continuing Education, Birkbeck College, University of London.(Bernasek \& Bunt, n.d.) While the partnership is no longer continued, today the College maintains its link to al-Azhar University in Cairo, one of the leading centres of Islamic Studies in the Muslim world, which has been renowned as an educational institution that promotes non-sectarian outlooks and dialogue across Muslim denominations.

\section{CONCLUSION}

There are four main findings that can be seen from our description above. Firstly, it is quite noticeable that The Muslim College has stated mission that is compatible with efforts to promote interfaith (and also intrafaith) understanding. Secondly, some of its lecturers/academics have been actively involved in various interfaith dialogues and initiatives, and ensured that its institution has certain awareness of the importance of interfaith and intrafaith understanding. Thirdly, The Muslim Colege has subjects in its curriculum that are relevant with efforts to develop mutual understanding across faiths. Fourthly, there are some existing successful collaborative partnerships in higher education betweeen universities and Muslim colleges, that are believed to be able to provide an opportunity to facilitate intercultural and interfaith understanding (Scott-Baumann \& Cheruvallil-Contractor, 2015, p. 134). As a result of a partnership with a university, students in Muslim colleges can have secular components added to their study. In these partnerships, a university may provide training for research methodologies, thereby building criticality, which is an important aspect of being open-minded in viewing interfaith or intrafaith relations. These partnerships, however, are not without obstacles. One of the most obvious is that of bureaucratic complexity.

The Muslim College has notably shown its pluralistic tendencies. Its tendency toward pluralism, respect and tolerance is, at first, expressed in its stated vision, mission, aims and objectives. Its mission statement can be considered to be around the following three general themes: 1) understanding between Muslims; 2) interfaith understanding, dialogue and cooperation; and 3) combination of Western and Islamic scholarship. The Muslim College, while having a Sunni background, states that it does not subscribe to any denomination, and seeks to encourage mutual respect and understanding between various Muslim communities.

\section{ACKNOWLEDMENTS}

This paper is part of the findings based on research conducted in the UK in August 2016. We would like to thank Syarif Hidayatullah State Islamic University Jakarta for funding our research.

\section{REFERENCES}

Abdullah, A. K. (2014). The Qurh, A. K. (2014). tom":[]\} CSL BIBLIOGRAPHYhematic Study of the Qur to. London \& Washington: The International Institute of Islamic Thought.

Awan, I., \& Zempi, I. (2015). We Fear for Our Lives: Offline and Online Experiences of Anti Muslim Hostility (Research). Birmingham City University, Nottingham Trent University and Tell MAMA.

Bernasek, L., \& Bunt, G. (n.d.). Islamic Studies Provision in the UK (Report to HEFCE by the Higher Education Academy).

Birt, Y., Hussain, D., \& Siddiqui, A. (Eds.). (2011). British Secularism and Religion: Islam, Society and the State. Leicestershire: Kube Publishing.

Commission on Religion and Belief in British Public Life. (2015). Living with Difference: Community, Diversity and the Common Good. Cambridge: The Woolf Institute.

DIke, A. H. (2009). Mosques Made in Britain. Quilliam.

Drammeh, A. M. (2016, August 10).

Gilliat-Ray, S. (2010). Muslims in Britain: An Introduction. Cambridge: Cambridge University Press.

Kessler, E. (2016, August 12).

Modood, T. (2015). August 12).ity Press.sity and the Common Good. ty and Tell MAMReligion in Britain: Challenges for Higher Education. London: Leadership Foundation for Higher Education.

O London: Leadership Foundender of His Faith. The Guardian. Retrieved from https://www.the 
guardian.com/world/2003/jan/15/terrorism.religio $\mathrm{n}$.

People of No Religion Outnumber Christians in England and Wales-Study. (n.d.). Retrieved from https://www.theguardian.com/world/2016/may/23 /no-religion-outnumber-christians-england-walesstudy
Scott-Baumann, A., \& Cheruvallil-Contractor, S. (2015). Islamic Education in Britain: New Pluralist Paradigms. London: Bloomsburry.

The Muslim Council of Britain. (2015). British Muslims in Number. London: The Muslim Council of Britain. 